\title{
Prevalence of malaria, prevention measures, and main clinical features in febrile children admitted to the Franceville Regional Hospital, Gabon
}

\author{
Sydney Maghendji-Nzondo ${ }^{1,4}$, Hermann Nzoughe ${ }^{1}$, Guy Joseph Lemamy ${ }^{3}$, Lady Charlene Kouna ${ }^{1}$, \\ Irene Pegha-Moukandja ${ }^{1}$, Faustin Lekoulou ${ }^{1}$, Bertrand Mbatchi ${ }^{4}$, Fousseyni Toure-Ndouo ${ }^{1}$, \\ and Jean Bernard Lekana-Douki ${ }^{1,2, *}$ \\ 1 Unité de Parasitologie Médicale (UPARAM), Centre International de Recherches Médicales de Franceville (CIRMF), \\ B.P. 769 Franceville, Gabon \\ 2 Département de Parasitologie-Mycologie Médecine Tropicale, Faculté de Médecine, Université des Sciences de la Santé, \\ B.P. 4009 Libreville, Gabon \\ 3 Département de Biologie Cellulaire et Génétique, Université des Science de la Santé, B.P. 4009 Libreville, Gabon \\ 4 Département de Biologie, Université des Sciences et Techniques de Masuku, B.P. 901, Franceville, Gabon
}

Received 6 February 2016, Accepted 25 July 2016, Published online 5 August 2016

\begin{abstract}
Recently, major progress has been made in controlling malaria in Africa. However, in Gabon, little information is available on the role of malaria in childhood febrile syndromes, the use and efficacy of preventive measures, and Plasmodium species distribution. Here, we characterized malaria in febrile children in Franceville, Gabon through a cross-sectional study at the pediatric unit of the Franceville Regional Hospital. We registered 940 febrile children. Their general condition was markedly altered in $11.7 \%$ of cases $(n=89 / 760)$; among them $19(21.4 \%)$ had a severely altered condition. Malaria was the second most frequent etiology $(22.0 \% ; n=162 / 738)$, after respiratory tract infections $(37.3 \% ; n=275 / 738)$. Children with malaria (63 \pm 39 months) were older than children without malaria (40 \pm 37 months) $(p=0.0013)$. Hemoglobin, red blood cell, white blood cell, and platelet values were lower in children with malaria than in those without malaria $(p<0.0001)$. Anemia was the most common feature of severe malaria $(70.6 \% ; n=12 / 17)$, followed by neurological involvement $(23.5 \% ; n=4 / 17)$. The prevalence of malaria was significantly higher in children older than 60 months than in younger children $(40 \%$ vs. $15.5 \% ; p<0.0001)$. Plasmodium falciparum accounted for $97.5 \%$ of cases $(158 / 162)$, followed by Plasmodium malariae $(2.5 \% ; n=4 / 162)$. Bed net use was high $(74.4 \% ; n=697 / 936)$ and contributed to malaria prevention $(p=0.001)$. Good basic knowledge of malaria also had a preventive effect $(p<0.0001)$. The prevalence of malaria in children in Franceville did not decrease significantly from 2009 to 2012 , remaining at about $20 \%$, highlighting that preventive measures should be reinforced.
\end{abstract}

Key words: Febrile syndrome, Preventive measures, Plasmodium, Species, Children, Gabon.

Résumé - Prévalence et mesures de prévention du paludisme et principales caractéristiques cliniques chez les enfants fébriles admis au centre hospitalier régional de Franceville au Gabon. Récemment, des progrès importants ont été accomplis dans la lutte contre le paludisme en Afrique. Cependant, au Gabon, peu d'informations sont disponibles sur le rôle du paludisme dans les syndromes fébriles des enfants, l'utilisation et l'efficacité de mesures de prévention, et la répartition des espèces de Plasmodium. Dans ce travail, nous avons caractérisé le paludisme chez les enfants fébriles à Franceville, au Gabon par une étude transversale à l'unité pédiatrique de l'Hôpital régional de Franceville. Nous avons enregistré 940 enfants fébriles. Leur état général était nettement altéré dans $11.7 \%$ des cas $(n=89 / 760)$, et sévèrement altéré chez 19 d'entre eux $(21.4 \%)$. Le paludisme était la deuxième étiologie la plus fréquente $(22.0 \% ; n=162 / 738)$, après les infections des voies respiratoires $(37.3 \% ; n=275 / 738)$. Les enfants atteints de paludisme étaient plus âgés (63 \pm 39 mois) que les enfants sans paludisme $(40 \pm 37$ mois) $(p<0.005)$. L'hémoglobine, les globules rouges, les globules blancs et les valeurs plaquettaires étaient plus faibles chez les enfants atteints de paludisme que chez ceux sans paludisme $(p<0.0001)$. L'anémie est la caractéristique la plus commune du paludisme grave $(70.6 \% ; n=12 / 17)$, suivie

\footnotetext{
*Corresponding author: lekana_jb@yahoo.fr
} 


\begin{abstract}
des atteintes neurologiques $(23.5 \% ; n=4 / 17)$. La prévalence du paludisme était significativement plus élevée chez les enfants âgés de plus de 60 mois que chez les enfants plus jeunes (40\% contre $15 \% ; p<0.0001)$. Plasmodium falciparum représentait $97.5 \%$ des cas (158/162), suivie par Plasmodium malariae $(2.5 \% ; n=4 / 162)$. L'utilisation des moustiquaires était répandue $(74 \% ; n=697 / 936)$ et a contribué à la prévention du paludisme $(p=0.001)$. Une bonne connaissance de base du paludisme a également un effet préventif $(p<0.0001)$. La prévalence du paludisme chez les enfants de Franceville n'a pas diminué de façon significative de 2009 à 2012, demeurant à environ $20 \%$, ce qui souligne que les mesures préventives doivent être renforcées.
\end{abstract}

\section{Introduction}

Febrile syndromes are one of the main reasons for pediatric consultations in developing countries and may be due to various viral, bacterial, and parasitic infections. Malaria is the most widespread febrile disease, present in 99 countries and territories. One-third of the world population is at risk, and malaria causes about one-fifth of all childhood deaths worldwide [13]. In 2013, there were an estimated 198 million cases of malaria and 584,000 deaths [42].

Five Plasmodium species infect humans, namely falciparum, vivax, malariae, ovale [33], and knowlesi, an emerging species [36]. Plasmodium falciparum is the most widespread and most lethal species in Africa, causing 95\% of symptomatic cases [33].

New antimalarial policies implemented in recent years have mainly concerned $P$. falciparum, although $P$. vivax and $P$. knowlesi can also cause life-threatening malaria [14, 19, 34]. Plasmodium knowlesi can cause cerebral hemorrhage, lung heaviness, and cardiac hemorrhage [6, 7]. Premature reticulocyte death due to $P$. vivax infection can cause severe anemia over a period of several months by blocking the formation of mature red blood cells [1].

Gabon is hyperendemic for malaria. Transmission is perennial because the equatorial climate favors mosquito proliferation and larval development. Changes in the national antimalarial policy, based on artemisinin combination therapy (ACT), distribution of impregnated bed nets, and intermittent preventive treatment during pregnancy, have led to a decline in the malaria burden in urban areas. Between 2005 and 2008, malaria prevalence dropped significantly from $31.2 \%$ to $18.3 \%$, followed by a recrudescence in 2011 in Libreville (24.1\%). In Franceville, malaria prevalence dropped from $69 \%$ (2004) to 19.5\% (2009). Between 2010 (17.9\%) and 2012 (21.45\%), no significant change was observed [2, 17, 20]. Artemether-lumefantrine (AL) and artesunate-amodiaquine (ASAQ) are both drugs in the co-first lines of treatment. Only three human species ( $P$. falciparum, $P$. malariae, and Plasmodium ovale) have been reported in Gabon [21, 31]. The most prevalent is $P$. falciparum (94-99\%), followed by $P$. malariae $(0.5-5 \%)$ and $P$. ovale $(0.5-2.4 \%)$. The near absence of human Plasmodium vivax infection in Central and Western Africa has been attributed to a low prevalence of the Duffy receptor in these populations [24]. However, cases of $P$. vivax infection have been described in Duffy (-) subjects in Uganda and Central Africa [8, 23, 29]. Surveillance of all malaria species will be necessary to eradicate the disease.

The aim of this study was to determine the place of malaria in febrile children consulting at the pediatric unit of the
Franceville Regional Hospital, Gabon, as well as its characteristics and the efficacy of preventive measures.

\section{Materials and methods}

\section{Ethics statement}

The study was approved by the Gabonese National Ethics Committee and the Ministry of Health ( $\mathrm{N}^{\circ}$ 00370/MSP/ CABMD). Blood samples were collected with the parents' or guardians' informed consent.

\section{Study location and population}

We conducted a cross-sectional study between April 2011 and May 2012 in the pediatric unit of the Amissa Bongo Regional Hospital in Franceville, the capital of the Haut-Ogooué Province, Gabon. Children between 6 and 168 months of age presenting an axillary temperature $>37.5^{\circ} \mathrm{C}$ or a $>24$-hour history of fever were recruited.

Global health alteration was classified as severe in the presence of anorexia, asthenia, and weight loss, and moderate in the presence of two of these symptoms. The alteration was defined as uncomplicated in the presence of only one of these three symptoms. Weight loss in the child was estimated by using the last weight recorded in the health book.

\section{Recording of preventive measures}

Data on the use of bed nets and insecticides, and some information on education and knowledge of malaria were collected with a questionnaire (Supplementary Material). The parents/guardians were asked whether their children slept under bed nets and whether they sprayed insecticide in their houses. To determine their level of education on malaria, we asked the following questions: "Do you know malaria? What is malaria? Do you know the modes of transmission of malaria? How can you avoid malaria?" Correct responses to these questions were considered a basic knowledge of malaria.

\section{Diagnosis}

The OptiMAL-IT ${ }^{\circledR}$ rapid diagnostic test (RDT) was used [27]. Parasite load was determined on blood smears using the Lambaréné method [30]. This method of counting slides is a variant of a method for counting thick films. Ten microliters of blood is evenly distributed on a 10 - by $18-\mathrm{mm}$ area 
of a microscope slide. Each high-power field (HPF) on this thick smear is 1/500th of a microliter (on a standard microscope at 1,000 magnification), and a count is made per 10 HPFs. The parasitemia per microliter is calculated by a precalibrated appropriate multiplication factor (500). Children with RDT or positive blood smears were considered to have malaria. Respiratory tract infections corresponding to colds and coughs, gastroenteritis corresponding to diarrhea and/or vomiting, dermatosis, ear, nose, and throat (ENT) infections, acute algetic syndromes, as well as clinical symptoms, such as pale conjunctivae and global health state alteration (anorexia, asthenia, and weight loss), were diagnosed by a physician according to clinical classification.

\section{Hematological analyses}

Routine hematological assays were performed with an automated blood cell counter $\left(\right.$ STKS ${ }^{\circledR}$, Coulter Corporation, USA). Blood $(5 \mathrm{~mL})$ was collected in EDTA tubes. Plasma was stored at $-20{ }^{\circ} \mathrm{C}$ and blood pellets were used for DNA extraction. Moderate anemia was defined by a hemoglobin level between 5 and $10 \mathrm{~g} / \mathrm{dL}$, and severe anemia by a hemoglobin level $\leq 5 \mathrm{~g} / \mathrm{dL}$.

\section{DNA extraction}

DNA from all children was extracted with the Omega Bio-Tek E.Z.N.A.1 method (Omega Bio-Tek, USA) according to the manufacturer's protocol [16]. Briefly, $250 \mu \mathrm{L}$ of blood ellets, $25 \mu \mathrm{L}$ of OB protease $(20 \mathrm{mg} / \mathrm{mL})$, and $250 \mu \mathrm{L}$ of lysis buffer were mixed and heated to $65{ }^{\circ} \mathrm{C}$ for $30 \mathrm{~min}$ before adding $260 \mu \mathrm{L}$ of isopropanol. The mixture was transferred to a column and centrifuged at $10,000 \mathrm{rpm}$ for $1 \mathrm{~min}$. The column was washed twice at 13,000 rpm for $2 \mathrm{~min}$, and DNA was eluted with $90 \mu \mathrm{L}$ of sterile water preheated to $65{ }^{\circ} \mathrm{C}$. DNA samples were kept at $-20{ }^{\circ} \mathrm{C}$ until use.

\section{Identification of Plasmodium species by RFLP-PCR}

Plasmodium speciation was based on nested PCR amplification of the cytochrome $b$ gene, followed by enzymatic restriction, as previously described [39]. Five microliters of DNA was amplified with $1 \mathrm{X}$ Taq polymerase buffer (Invitrogen), $0.8 \mu \mathrm{M}$ of each primer (Plas 1 and $2 \mathrm{a}$ for primary PCR and Plas 3 and 4 for nested PCR), $0.2 \mathrm{mM} \mathrm{dNTP}$ (Invitrogen), $2 \mathrm{mM} \mathrm{MgCl}$, and $0.024 \mathrm{U}$ of Taq DNA polymerase (Invitrogen), using the following cycling program: $5 \mathrm{~min}$ at $94{ }^{\circ} \mathrm{C}$, followed by 35 cycles of $30 \mathrm{~s}$ at $94{ }^{\circ} \mathrm{C}, 45 \mathrm{~s}$ at $58{ }^{\circ} \mathrm{C}, 45 \mathrm{~s}$ at $72{ }^{\circ} \mathrm{C}$, and a final extension step for $7 \mathrm{~min}$ at $72{ }^{\circ} \mathrm{C}$. PCR products were detected by $2 \%$ agarose gel electrophoresis. In order to distinguish the four species of Plasmodium (falciparum, malariae, ovale, and vivax), restriction fragment length polymorphism (RFLP) analysis was performed using the restriction enzyme AluI (New England Biolabs, UK). PCR primers and Plasmodium species profiles after AluI enzyme digestion are shown in Table 1. DNA products were detected by electrophoresis on $2 \%$ agarose gel.

\section{Statistical analysis}

Statistical analyses were carried out with Epi-info version 3.3.2 (2005, CDC, Atlanta, USA) and STATA version 10 (Stata Corp, College Station, USA). Age was expressed as the median and interquartile range (IQR), and parasite density as the geometric mean (GMPD). The Chi-square test was used to compare categorical variables, and the non-parametric Mann-Whitney $U$ test, Pearson's test, and Fisher's exact test were used for group comparisons, as appropriate. $p$ values $<0.05$ were considered to indicate statistical significance.

\section{Results}

\section{Study population}

A total of 940 children were included: 556 in 2011 and 384 in 2012. The sex ratio was $1.1(489 \mathrm{M} / 451 \mathrm{~F})$. Ages were recorded for only 931 children. Children aged between 6 and 60 months represented $72.6 \%(676 / 931)$ of the patients, and children over 60 months 27.4\% (255/931). The general characteristics of the children are summarized in Table 2. Mean body temperature was $38.3 \pm 1.1{ }^{\circ} \mathrm{C}$. Hematological values were normal.

Clinical examination showed that the global health state was altered in $11.7 \%(89 / 760)$ of children, among these $78.6 \%$ (70/89) were moderate and $21.4 \%$ (19/89) severe. Conjunctival examination in 728 children showed a normal aspect in 235 cases $(32.3 \%)$, a pale conjunctival aspect in 451 cases $(61.9 \%)$, and a reddish aspect in 42 cases $(5.8 \%)$.

The causes (etiology) of fever were investigated in 738 cases (Fig. 1). The most prevalent cause was a respiratory tract infection $(37.3 \% ; n=275)$, followed by malaria $(22.0 \%$; $n=162)$. Gastroenteritis and other causes were found in $9.6 \%(n=71)$ and $9.8 \%(n=72)$ of cases, respectively. Dermatoses, ENT infections, and an acute algetic syndrome were responsible for fever in $4.3 \%(n=32), 3.7 \%(n=27)$, and $3.1 \%(n=23)$ of cases, respectively. The cause of fever was undetermined in $10.3 \%$ of cases $(n=76)$.

\section{Effect of malaria on hematological parameters and age distribution}

The mean age of the Plasmodium-infected patients (63.4 \pm 39.4 months) was significantly higher than that of the other children $(40.3 \pm 37.1$ months $)(p=0.0013)$, (Table 3 ). The body temperature of the Plasmodium-infected children $\left(38.5 \pm 1.1^{\circ} \mathrm{C}\right)$ was higher than that of the other children $\left(38.2 \pm 0.9{ }^{\circ} \mathrm{C}\right)(p=0.001)$. Hemoglobin, red blood cell, white blood cell, and platelet values were lower in Plasmodium-infected children than in uninfected children $(p<0.0001)$. The mean interval between symptom onset and consultation was 3 days in both Plasmodium-infected and uninfected children.

\section{Characteristics of plasmodial infection}

The overall prevalence of Plasmodium infection was $22.2 \%(n=209 / 940)$ by RDT and $18.8 \%$ on blood smear examination $(n=166 / 881)(p=0.08)$. The sex ratio was 
Table 1. Sequences of primer sets and restriction fragments for each species.

\begin{tabular}{|c|c|c|c|c|c|c|c|}
\hline \multirow[t]{2}{*}{ Gene } & & \multirow[t]{2}{*}{ Primers } & \multirow[t]{2}{*}{$T\left({ }^{\circ} \mathrm{C}\right)$} & \multicolumn{4}{|c|}{ Sizes of PCR products after Alu I restriction (bp) } \\
\hline & & & & P. falciparum & P. malariae & P. ovale & P. vivax \\
\hline \multirow[t]{3}{*}{ Cytochrome b } & PCR 1 & $\begin{array}{l}5^{\prime} \text {-GAGAATTATGGAGTGGATGGTG-3' } \\
5^{\prime} \text {-GTGGTAATTGACATCCWATCC-3' }\end{array}$ & 58 & 640 & 381 & 584 & \\
\hline & PCR 2 & 5'-GGTGTTTYAGATAYATGCAYGC-3' & & & 249 & 224 & $249 / 270$ \\
\hline & & 5'-CATCCWATCCATARTAWAGCATAG-3' & & 159 & 187 & & $187 / 169 / 111$ \\
\hline
\end{tabular}

$1.2(115 \mathrm{M} / 94 \mathrm{~F})$ in the Plasmodium-infected group and 1.1 $(374 \mathrm{M} / 355 \mathrm{~F})$ in the uninfected group $(p=0.4)$. The mean values of parasitemia were calculated based on the 166 samples that tested positive by thick film only. Mean Plasmodium parasitemia was $9581(50-600,000) \mathrm{p} / \mu \mathrm{L}$ of blood. The prevalence of malaria was similar in 2011 [23\% $(n=128 /$ $556)]$ and $2012[21.1 \%(n=81 / 384)](p=0.5)$. The temporal distribution of the parasite infection with the seasons shows that overall prevalence of Plasmodium infection was not the same depending on the season in 2011-2012 $(p=0.02)$ (Fig. 2). The prevalence of Plasmodium infection was significantly lower during the long rainy season in 2011 $(15.8 \%)$, and during the long rainy season (14\%) and long dry season $(13.2 \%)$ in 2012 . It was highest during the short rainy seasons $(29.8 \%$ and $26.4 \%)$ in 2012 and $2011(p<0.04)$.

Among the Plasmodium-infected children, 8.1\% (17/209) had one sign of severe malaria. Severe anemia was the most prevalent sign $[70.6 \%(12 / 17)]$, followed by neurological involvement $[23.5 \%(4 / 17)]$. There was one case of prostration $(5.9 \%)$.

The maximum age among the Plasmodium-infected children was 172 months. The prevalence was significantly lower in children under 60 months of age [15.5\% (105/676)] than in children over 60 months $[40 \% \quad(102 / 255)]$ $\left(p=2.4 \times 10^{-15}\right)$ (Table 4). The prevalence was lower in children under 12 months of age [2.5\% (5/198)] than in the other age groups $(p<0.00001)$. The prevalence was similar in children over 108 months of age $(36.5 \%)$ and in those between 37 and 108 months [(40.4\%; $n=147 / 364$ $(p=0.7)]$. The prevalence was significantly lower in the 13-36 months age group [17.5\% (55/315)] than in older age groups $(p<0.05)$, and significantly lower from 37 to 60 months $[27.6 \%(45 / 163)]$ than from 61 to 84 months $[40.8 \%$ $(42 / 103)]$ and from 85 to 108 months [43.3\% (29/67)] $(p=0.02)$. Mean parasitemia was significantly lower in children aged 37-60 months $[7,421(200-160,000) \mathrm{p} / \mu \mathrm{L}]$ than in those aged 61-84 months [16,832 (200-600,000) p/ $\mu \mathrm{L}]$, $(p=0.04)$. Parasitemia was also significantly higher in children aged from 61 to 84 months, and lowest in children over 108 months $[5,804(1,000-600,000) \mathrm{p} / \mu \mathrm{L}],(p=0.01)$. Finally, we observed a significant difference in mean parasitemia between children aged 85 and 108 months $[22,971(1,000-340,000) \mathrm{p} / \mu \mathrm{L}]$ and those over 108 months [7,139 $(1,000-125,000) \mathrm{p} / \mu \mathrm{L}],(p=0.02)$.

\section{Distribution of Plasmodium species}

Molecular diagnosis was based on amplification of an $816 \mathrm{bp}$ fragment of the Cytb gene. Speciation was based on
Table 2. General characteristics of the included patients.

\begin{tabular}{lc}
\hline & Mean \pm standard deviation \\
\hline Parameters & $45.2 \pm 38.8$ \\
Age (months) & $38.3 \pm 1.1$ \\
Temperature $\left({ }^{\circ} \mathrm{C}\right)$ & $10.7 \pm 2.1$ \\
Hemoglobin $(\mathrm{g} / \mathrm{dL})$ & $10,197 \pm 6,337.4$ \\
White blood cells $(/ \mu \mathrm{L})$ & $3,852,112.7 \pm 806,732.2$ \\
Red blood cells $(/ \mu \mathrm{L})$ & $286,054.8 \pm 157,151.7$ \\
Platelets $(/ \mu \mathrm{L})$ & \\
\hline
\end{tabular}

enzymatic digestion (RFLP) of PCR products. Plasmodium falciparum was characterized by two DNA fragments (640 and $159 \mathrm{bp}$ ), and $P$. malariae by three fragments (187, 249, and $381 \mathrm{bp}$ ). Only 162 PCR products could be digested, because of insufficient yield and the low sensitivity of the primer set used. We found that $158(97.5 \%)$ infections were due to $P$. falciparum, and $4(2.5 \%)$ to $P$. malariae. No mixed infections and no $P$. ovale, or $P$. vivax infections were found.

\section{Preventive measures}

Finally, we analyzed the patients' sociodemographic characteristics and use of preventive measures (Table 5). We found that bed nets were used by $74.5 \%$ of patients (697/936). The frequency of bed net use was significantly higher among children without malaria $[76.9 \%, n=561 / 729]$ than among children with malaria [65.7\%, $n=136 / 207]$, $(p=0.001)$. The use of window nets $[14.7 \%, n=137 / 935]$ had no preventive effect $(p=0.4)$, and neither did the use of insecticide house spraying [respectively, 29.6\% (216/729) and $22.7 \%(47 / 207)]$ in children without and with malaria $(p=0.06)$. Insecticide sprays were used in $28.1 \%$ of homes $(n=263 / 936)$. The parents/guardians of children with and without malaria were aware of essential information on malaria in, respectively, 51\% $(n=105 / 207)$ and $71.3 \%(n=519 / 728)$ of cases $\left(p=4.8 \times 10^{-8}\right)$.

\section{Discussion}

Elimination or eradication of malaria is a new major challenge in some endemic areas. Herein, we assessed the epidemiology of malaria in febrile children in South-East Gabon (Franceville). More than three-fourth of febrile children reporting to the Franceville Regional Hospital during the study period had an altered global health state, probably linked to a high prevalence of anemia, as indicated by the large proportion 


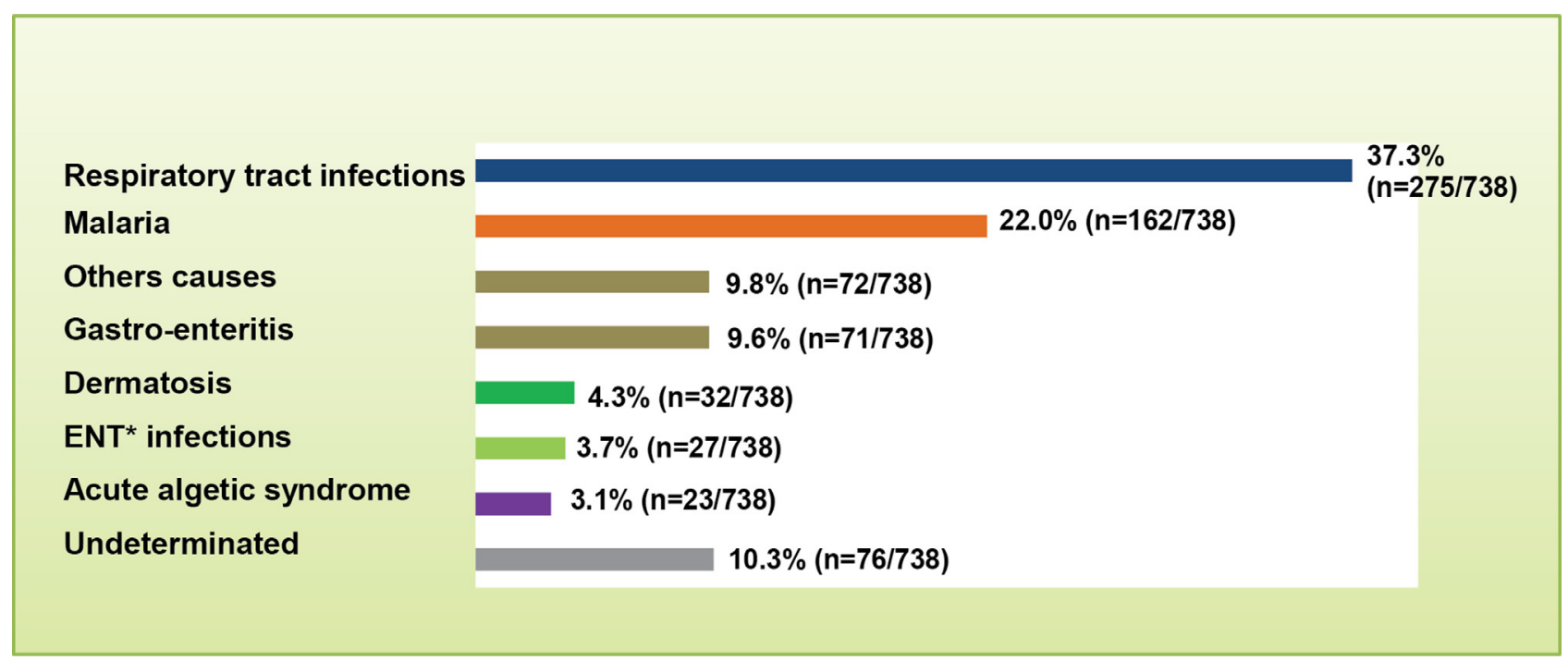

Figure 1. Distribution of certain fever diseases diagnosed in the children included in the study. *Ear, nose, and throat infections.

Table 3. Comparison of characteristics between Plasmodium uninfected versus infected children (diagnosed by RDT and blood smear).

\begin{tabular}{lccc}
\hline & \multicolumn{2}{c}{ Mean \pm standard deviation } & $p$ \\
\cline { 2 - 3 } & Uninfected $(N=731)$ & Infected $(N=209)$ & 0.001 \\
Age (months) & $40.3 \pm 37.1$ & $63.4 \pm 39.4$ & 0.001 \\
Temperature $\left({ }^{\circ} \mathrm{C}\right)$ & $38.2 \pm 0.9$ & $38.5 \pm 1.1$ & $4.95 \times 10^{-18}$ \\
Hemoglobin $(\mathrm{g} / \mathrm{dL})$ & $11.0 \pm 1.8$ & $9.6 \pm 2.6$ & $7.93 \times 10^{-6}$ \\
White blood cells $\left(\times 10^{3} / \mu \mathrm{L}\right)$ & $10.8 \pm 6.3$ & $8.6 \pm 6.4$ & $2.27 \times 10^{-18}$ \\
Red blood cells $\left(\times 10^{6} / \mu \mathrm{L}\right)$ & $3.9 \pm 0.7$ & $3.5 \pm 0.9$ & $1.47 \times 10^{-29}$ \\
Platelets $\left(\times 10^{3} / \mu \mathrm{L}\right)$ & $321.6 \pm 144.6$ & $188.6 \pm 147.4$ & \\
Parasitemia $(\mathrm{geometric}$ mean and quartile) & & $9,581(50-600,000)$ & \\
\hline
\end{tabular}

of children with conjunctival pallor. Similar results have been obtained in Tanzania [25]. We confirm that children aged less than 5 years are the most likely to present fever [37], and that infectious diseases account for fever in $80 \%$ of these children. Low hemoglobin levels are due to parasite-induced hemolysis [3]. Indeed, $P$. falciparum antigens, such as RSP2/RAP2, could be transferred to the surface of uninfected and infected red blood cells, reducing their deformability, inducing their sequestration by the spleen, accelerating both complement-mediated lysis as well as macrophage uptake, leading to anemia [11]. Plasmodium falciparum infection also modulates the cytokine balance, leading to erythrocyte clearance [26]. However, malnutrition and digestive parasitic infections are also causes of anemia [15, 44].

In addition, we confirm that malaria is the second leading cause of fever among children in Franceville, after respiratory tract infections [4, 17]. Gastroenteritis was the third most common cause of fever, as also reported in Tanzania, where malaria was the second leading cause of fever [9]. Although we did not explore the pathogens responsible for respiratory tract infections, a recent report from Gabon (including Franceville) showed that the most prevalent are influenza-like viruses (adenoviruses, parainfluenza viruses, enteroviruses, respiratory syncytial viruses, and influenza viruses) [18]. The cause of fever remained undetermined in
$10 \%$ of children, underlining the shortcomings of the Gabonese healthcare facilities.

Our findings confirm that malaria mainly affects older febrile children in Gabon [20]. However, our findings are based only on children in consultation at our study sites; we do not have information on malaria distribution in the overall population. Children under 5 years are more often protected by bed nets and other preventive measures than older children whose prevention measures are often unavailable. We found an overall high rate of bed net use. Insecticide-treated bed nets have been shown to significantly reduce the incidence, severe forms, and lethality of malaria, especially among children under five years old. As in several other African countries, the use of bed nets has contributed to the decline in the malaria burden in Gabon [40]. It should be noted that information on the use of bed nets in this study was based on the verbal statements of parents/guardians, and that bed net condition (presence of holes, insecticide impregnation) was not verified.

We found that children under seven years of age tended to have lower parasite loads. The same result has been reported after the increased coverage of insecticide-treated bed nets and the decrease of malaria transmission in some countries [38, 43]. However, parasitemia tended to be lower after 108 months of age, a finding consistent with acquisition of semi-immunity. 


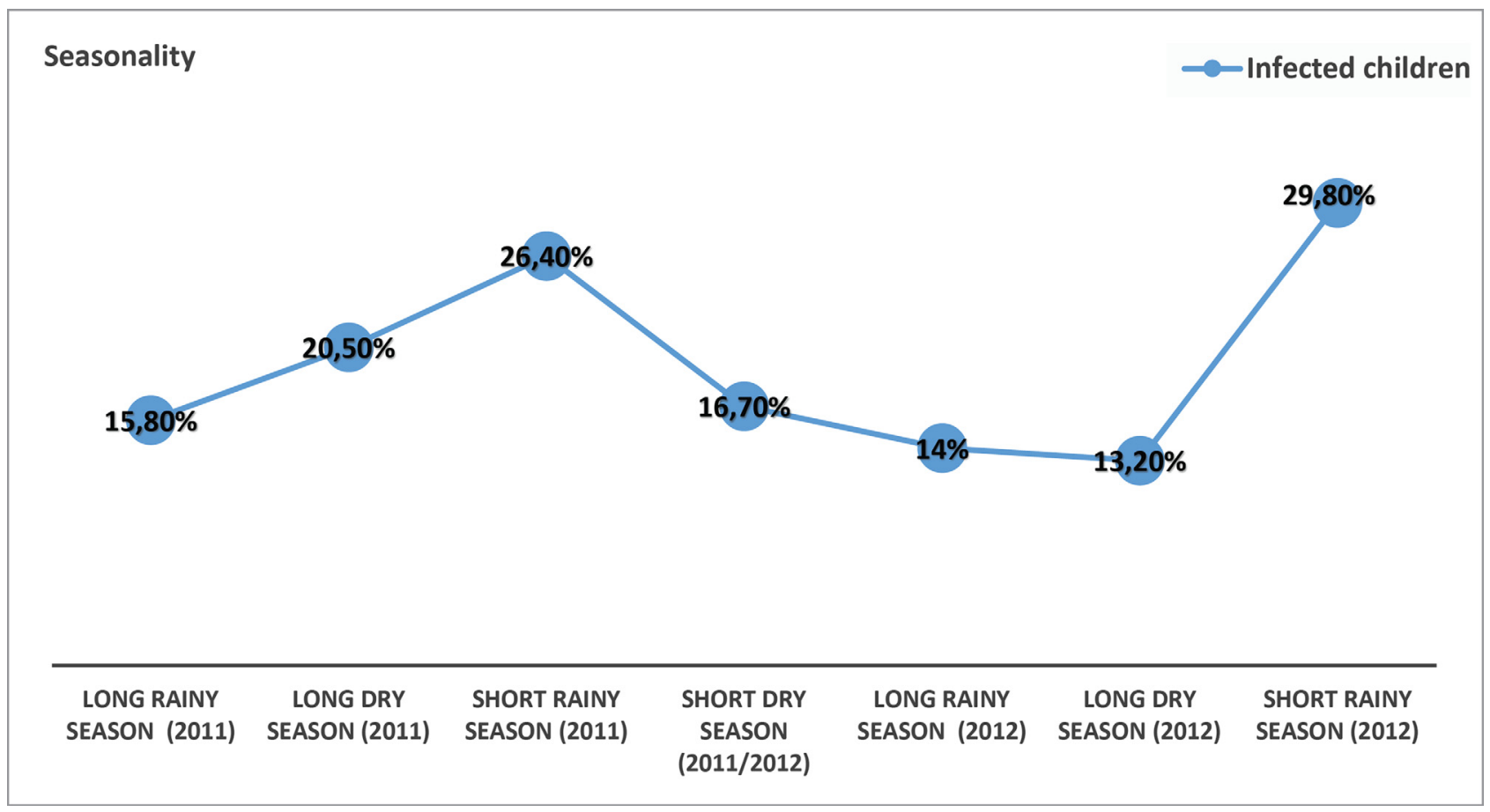

Figure 2. Temporal distribution of plasmodial infection.

Table 4. Prevalence of malaria infection according to age group in children $(n=931)$ (children diagnosed by RDT and blood smear).

\begin{tabular}{|c|c|c|c|c|c|c|}
\hline & \multicolumn{6}{|c|}{ Age group (months) } \\
\hline & $6-12$ & $13-36$ & $37-60$ & $61-84$ & $85-108$ & $>108$ \\
\hline $\begin{array}{l}\text { Prevalence \%, } \\
(n / N)\end{array}$ & $2.5,(5 / 198)$ & $17.5,(55 / 315)$ & $27.6,(45 / 163)$ & $40.8,(42 / 103)$ & $43.3,(29 / 67)$ & $36.5,(31 / 85)$ \\
\hline $\begin{array}{l}\text { Parasitemia } \\
(\mathrm{p} / \mu \mathrm{L})\end{array}$ & $\begin{array}{c}1,854 \\
(50-143,000)\end{array}$ & $\begin{array}{c}18,624 \\
(1000-446,333)\end{array}$ & $\begin{array}{c}12,132 \\
(300-160,000)\end{array}$ & $\begin{array}{c}24,065 \\
(200-600,000)\end{array}$ & $\begin{array}{c}27,091 \\
(1000-340,000)\end{array}$ & $\begin{array}{c}7,139 \\
(1000-125,000)\end{array}$ \\
\hline
\end{tabular}

$\%$ : percentage; $n$ : number of infected children; $N$ : number of recruited children.

The low frequency of malaria in children less than 12 months is consistent with maternal immune protection through breast-feeding. The higher prevalence of malaria among febrile children over 5 years is consistent with reports from Rwanda [32], where the risk was highest in the 5- to 15-year-old age group. A similar age distribution has been reported in asymptomatic Nigerian children [28]. This could suggest a delay in immunity acquisition, because of the use of preventive measures that limit the contact between children and the parasite. Children aged 5 to 15 years could thus represent a reservoir for Plasmodium. Surprisingly, the data indicate that malaria prevalence was highest in the short rainy seasons. Indeed, breeding sites in this season are maintained while they are cleaned in long rainy seasons.

We confirm the decrease in the malaria burden in Franceville in recent years, despite its stability since 2009 [17]. In contrast, however, a recrudescence has been reported in febrile children up to $24.1 \%$ in Libreville, capital of Gabon, after the decline observed between 2000 and 2009 [5, 20]. This could be explained by different socioeconomic contexts and/or plasmodial transmission rates, and by a decrease in free distribution of impregnated bed nets and awareness campaigns on malaria. Since the year 2008, Gabon has lost a global grant.

Hematological values were lower in Plasmodium-infected children than in other febrile children. This is consistent with red blood cell lysis and platelet sequestration induced by $P$. falciparum, as recently reported in India [35]. We confirm that malaria is also associated with a loss of white blood cells [22]. Severe malaria anemia was found in $70.6 \%$ of our patients with severe malaria, consistent with data from Libreville, Gabon [12].

Plasmodium falciparum was responsible for the majority of cases of malaria in this study, as reported elsewhere in Gabon $[21,31]$. This suggests that, despite the decrease in the malaria burden in Gabon, the species distribution in febrile children has not changed. In contrast, among asymptomatic individuals living in rural areas of Gabon, it was recently reported that P. malariae and $P$. ovale accounted for, respectively, $47.6 \%$ and $9.9 \%$ of cases [10]. This could suggest selection of $P$. falciparum to the detriment of other species during acute 
Table 5. Preventive measures between malaria infected and uninfected patients.

\begin{tabular}{lccccc}
\hline & \multicolumn{2}{c}{ Number of children } & & \\
\cline { 2 - 3 } Prevention measures & Uninfected & Infected & $p$ & Odds ratio CI 95\% \\
\hline Bed net & $561(76.9 \%)$ & $136(65.7 \%)$ & 0.001 & $1.74[1.2-2.4]$ \\
Insecticides & $216(29.6 \%)$ & $47(22.7 \%)$ & 0.06 & $1.4[1-2.05]$ \\
Window net & $111(15.3 \%)$ & $26(12.6 \%)$ & 0.4 & $1.3[0.8-1.9]$ \\
Receiving Information, Education and Knowledge (IEK) on malaria & $519(71.3 \%)$ & $105(51 \%)$ & $4.8 \times 10^{-8}$ & $2.4[1.7-3.3]$ \\
\hline
\end{tabular}

malaria. Another possible explanation is the use of different diagnostic methods. Delicat-Loembet et al used 454 sequencing to identify Plasmodium species, while we and other authors used less sensitive methods (PCR-RFLP, and blood smear with RDT, respectively). Despite the non-detection of $P$. ovale in our study, this species is occasionally found in Franceville, and we have diagnosed one case of $P$. ovale infection since the end of this study. The low sensitivity of the PCR can be explained by insufficient yield and the low sensitivity of the primer set used. We confirm that $P$. vivax does not circulate in humans in Franceville, and neither does P. knowlesi, a primate species that causes some episodes of severe malaria in humans [41].

We found that $66.7 \%$ of parents/guardians had a good knowledge of malaria, and confirm that this knowledge is associated with a lower risk of childhood malaria. Surprisingly, the use of window nets and insecticide sprays was not associated with a lower risk of malaria, possibly because few parents/guardians used these two measures.

We confirm the stability of the malaria burden in Franceville, Gabon, implying that stronger preventive measures are needed to reduce it further. Studies are also needed to evaluate the malaria burden throughout Gabon.

\section{Conflict of interests}

The authors declare no conflict of interest in relation with this paper.

Acknowledgements. We are grateful to the children and their parents who accepted to participate in the study, and to the staff of the pediatric wards (particularly Dr. Avoum, Dr. Ekaghba, and Patrician of the laboratory of Centre Hospitalier Regional Amissa Bongo, Franceville). We also thank Heïdi Lançon for the English revision of the manuscript. We also thank the staff of the Medical Parasitology Unit at the Centre International de Recherches Médicales de Franceville (CIRMF). This work was supported by the CIRMF, the Gabonese government, and Total Gabon.

\section{References}

1. Antia R, Yates A, de Roode JC. 2008. The dynamics of acute malaria infections. I. Effect of the parasite's red blood cell preference. Proceedings of the Royal Society B, 275(1641), $1449-1458$.

2. Biteghe Bi Essone JC, Iroungou BA, Lekana-Douki JB, Touré Ndouo FS, Onanga R, Ollomo B. 2014. Submicroscopic infection from uncomplicated Plasmodium falciparum malaria of Franceville, southeastern Gabon. International Journal of Advanced Research, 2(1), 117-123.

3. Bloland PB, Lackritz EM, Kazembe PN, Were JB, Steketee R, Campbell CC. 1993. Beyond chloroquine: implications of drug resistance for evaluating malaria therapy efficacy and treatment policy in Africa. Journal of Infectious Diseases, 167(4), 932-937.

4. Bouyou-Akotet MK, Mawili-Mboumba DP, Kendjo E, Eyang Ekouma A, Abdou Raouf O, Engohang Allogho E, Kombila M. 2012. Complicated malaria and other severe febrile illness in a pediatric ward in Libreville, Gabon. BMC Infectious Diseases, 12, 216.

5. Bouyou-Akotet MK, Mawili-Mboumba DP, Kendjo E, MabikaMamfoumbi M, Ngoungou EB, Dzeing-Ella A, PembaMihindou M, Ibinga E, Efame-Eya E, Planche T, Kremsner PG, Kombila M. 2009. Evidence of decline of malaria in the general hospital of Libreville, Gabon from 2000 to 2008. Malaria Journal, 8, 300.

6. Cox-Singh J. 2010. Malaria: what can apes teach humans? Future Microbiology, 5(8), 1157-1160.

7. Cox-Singh J, Hiu J, Lucas SB, Divis PC, Zulkarnaen M, Chandran P, Wong KT, Adem P, Zaki SR, Singh B, Krishna S. 2010. Severe malaria - a case of fatal Plasmodium knowlesi infection with post-mortem findings: a case report. Malaria Journal, 9, 10.

8. Culleton R, Ndounga M, Zeyrek FY, Coban C, Casimiro PN, Takeo S, Tsuboi T, Yadava A, Carter R, Tanabe K. 2009. Evidence for the transmission of Plasmodium vivax in the Republic of the Congo, West Central Africa. Journal of Infectious Diseases, 200(9), 1465-1469.

9. D'Acremont V, Kaiser L, Genton B. 2014. Causes of fever in outpatient Tanzanian children. New England Journal of Medecine, 370(23), 2243-2244.

10. Delicat-Loembet L, Rougeron V, Ollomo B, Arnathau C, Roche B, Elguero E, Moukodoum ND, Okougha AP, Mve Ondo B, Boundenga L, Houze S, Galan M, Nkoghe D, Leroy EM, Durand P, Paupy C, Renaud F, Prugnolle F. 2015. No evidence for ape Plasmodium infections in humans in Gabon. PLoS One, 10(6), e0126933.

11. Douki JB, Sterkers Y, Lepolard C, Traore B, Costa FT, Scherf A, Gysin J. 2003. Adhesion of normal and Plasmodium falciparum ring-infected erythrocytes to endothelial cells and the placenta involves the rhoptry-derived ring surface protein-2. Blood, 101(12), 5025-5032.

12. Dzeing-Ella A, Nze Obiang PC, Tchoua R, Planche T, Mboza B, Mbounja M, Muller-Roemer U, Jarvis J, Kendjo E, Ngou-Milama E, Kremsner PG, Krishna S, Kombila M. 2005. Severe falciparum malaria in Gabonese children: clinical and laboratory features. Malaria Journal, 4, 1.

13. Feachem RG, Phillips AA, Hwang J, Cotter C, Wielgosz B, Greenwood BM, Sabot O, Rodriguez MH, Abeyasinghe RR, 
Ghebreyesus TA, Snow RW. 2010. Shrinking the malaria map: progress and prospects. Lancet, 376(9752), 1566-1578.

14. Garcia LS. 2010. Malaria. Clinics in Laboratory Medecine, 30(1), 93-129.

15. Khan JR, Awan N, Misu F. 2016. Determinants of anemia among 6-59 months aged children in Bangladesh: evidence from nationally representative data. BMC Pediatrics, 16, 3.

16. Lekana-Douki JB, Dinzouna Boutamba SD, Zatra R, Zang Edou SE, Ekomy H, Bisvigou U, Toure-Ndouo FS. 2011. Increased prevalence of the Plasmodium falciparum Pfmdrl $86 \mathrm{~N}$ genotype among field isolates from Franceville, Gabon after replacement of chloroquine by artemether-lumefantrine and artesunate-mefloquine. Infection, Genetics and Evolution, 11(2), 512-517.

17. Lekana-Douki JB, Pontarollo J, Zatra R, Toure-Ndouo FS. 2011. Paludisme au Gabon : résultats d'une étude bioclinique à l'hôpital de l'amitié sino-gabonaise de Franceville. Cahier Santé, 21(4), 193-198.

18. Lekana-Douki SE, Nkoghe D, Drosten C, Ngoungou EB, Drexler JF, Leroy EM. 2014. Viral etiology and seasonality of influenza-like illness in Gabon, March 2010 to June 2011. BMC Infectious Diseases, 14, 373.

19. Maguire JD, Baird JK. 2010. The "non-falciparum" malarias: the roles of epidemiology, parasite biology, clinical syndromes, complications and diagnostic rigour in guiding therapeutic strategies. Annals of Tropical Medicine and Parasitology, 104(4), 283-301.

20. Mawili-Mboumba DP, Bouyou Akotet MK, Kendjo E, Nzamba J, Medang MO, Mbina JR, Kombila M. 2013. Increase in malaria prevalence and age of at risk population in different areas of Gabon. Malaria Journal, 12, 3.

21. Mawili-Mboumba DP, Bouyou Akotet MK, Ngoungou EB, Kombila M. 2010. Evaluation of rapid diagnostic tests for malaria case management in Gabon. Diagnostic Microbiology and Infectious Disease, 66(2), 162-168.

22. McKenzie FE, Prudhomme WA, Magill AJ, Forney JR, Permpanich B, Lucas C, Gasser RA Jr, Wongsrichanalai C. 2005. White blood cell counts and malaria. Journal of Infectious Diseases, 192(2), 323-330.

23. Mendes C, Dias F, Figueiredo J, Mora VG, Cano J, de Sousa B, do Rosario VE, Benito A, Berzosa P, Arez AP. 2011. Duffy negative antigen is no longer a barrier to Plasmodium vivax molecular evidences from the African West Coast (Angola and Equatorial Guinea). PLoS Neglected Tropical Diseases, 5(6), e1192.

24. Mercereau-Puijalon O, Menard D. 2010. Plasmodium vivax and the Duffy antigen: a paradigm revisited. Transfusion Clinique et Biologique, 17(3), 176-183.

25. Mogensen CB, Sorensen JE, Bjorkman A. 2006. Pallor as a sign of anaemia in small Tanzanian children at different health care levels. Acta Tropica, 99(2-3), 113-118.

26. Mohan K, Sam H, Stevenson MM. 1999. Therapy with a combination of low doses of interleukin 12 and chloroquine completely cures blood-stage malaria, prevents severe anemia, and induces immunity to reinfection. Infection and Immunity, 67(2), 513-519.

27. Moody AH, Chiodini PL. 2002. Non-microscopic method for malaria diagnosis using OptiMAL IT, a second-generation dipstick for malaria pLDH antigen detection. British Journal of Biomedical Science, 59(4), 228-231.

28. Noland GS, Graves PM, Sallau A, Eigege A, Emukah E, Patterson AE, Ajiji J, Okorofor I, Oji OU, Umar M,
Alphonsus K, Damen J, Ngondi J, Ozaki M, Cromwell E, Obiezu J, Eneiramo S, Okoro C, McClintic-Doyle R, Oresanya O, Miri E, Emerson PM, Richards FO Jr. 2014. Malaria prevalence, anemia and baseline intervention coverage prior to mass net distributions in Abia and Plateau States, Nigeria. BMC Infectious Disease, 14, 168.

29. Oliveira-Ferreira J, Lacerda MV, Brasil P, Ladislau JL, Tauil PL, Daniel-Ribeiro CT. 2010. Malaria in Brazil: an overview. Malaria Journal, 9, 115.

30. Planche T, Krishna S, Kombila M, Engel K, Faucher JF, NgouMilama E, Kremsner PG. 2001. Comparison of methods for the rapid laboratory assessment of children with malaria. The American Journal of Tropical Medicine and Hygiene, 65(5), 599-602.

31. Richard-Lenoble DKM, Chandenier J, Gay F, Billiault X, Nguiri C, Martz M, Boyer F, Bauzou M. 1987. Le paludisme au Gabon. II: Évaluation des prévalences parasitaires qualitatives et quantitatives sur l'ensemble du pays en milieu scolaire et préscolaires. Bulletin de la Société de Pathologie Exotique, 80(3 Pt 2), 532-542.

32. Rulisa S, Kateera F, Bizimana JP, Agaba S, Dukuzumuremyi J, Baas L, de Dieu Harelimana J, Mens PF, Boer KR, de Vries PJ. 2013. Malaria prevalence, spatial clustering and risk factors in a low endemic area of Eastern Rwanda: a cross sectional study. PLoS One, 8(7), e69443.

33. Sachdev HS, Mohan M. 1985. Vivax cerebral malaria. Journal of Tropical Pediatrics, 31(4), 213-215.

34. Santos-Ciminera PD, Roberts DR, Alecrim MG, Costa MR, Quinnan GV Jr. 2007. Malaria diagnosis and hospitalization trends, Brazil. Emerging Infectious Diseases, 13(10), $1597-1600$

35. Singh R, Kumar S, Rana SK, Thakur B, Singh SP. 2013. A comparative study of clinical profiles of vivax and falciparum malaria in children at a tertiary care centre in uttarakhand. Journal of Clinical and Diagnostic Research, 7(10), 2234-2237.

36. Sinton JA, Mulligan HW. 1932. A critica review of the litterature relating to the identification of the malaria parasites recorded from monkeys of family Cercopithecidae and Colobidae. Records of the Malaria Survey of India, III, 357-380.

37. Smith T, Felger I, Tanner M, Beck HP. 1999. Premunition in Plasmodium falciparum infection: insights from the epidemiology of multiple infections. Transactions of the Royal Society of Tropical Medicine and Hygiene, 93(Suppl 1), 59-64.

38. Smith T, Hii JL, Genton B, Muller I, Booth M, Gibson N, Narara A, Alpers MP. 2001. Associations of peak shifts in ageprevalence for human malarias with bednet coverage. Transactions of the Royal Socety of Tropical Medicine and Hygiene, 95(1), 1-6.

39. Steenkeste N, Incardona S, Chy S, Duval L, Ekala MT, Lim P, Hewitt S, Sochantha T, Socheat D, Rogier C, MercereauPuijalon O, Fandeur T, Ariey F. 2009. Towards high-throughput molecular detection of Plasmodium: new approaches and molecular markers. Malaria Journal, 8, 86.

40. Tokponnon FT, Ogouyemi AH, Sissinto Y, Sovi A, Gnanguenon V, Cornelie S, Adeothy AA, Osse R, Wakpo A, Gbenou D, Oke M, Kinde-Gazard D, Kleinschmidt I, Akogbeto MC, Massougbodji A. 2014. Impact of long-lasting, insecticidal nets on anaemia and prevalence of Plasmodium falciparum among children under five years in areas with highly resistant malaria vectors. Malaria Journal, 13, 76.

41. White NJ. 2008. Plasmodium knowlesi: the fifth human malaria parasite. Clinical Infectious Diseases, 46(2), 172-173. 
42. WHO. 2014. World malaria report 2014. World Health Organisation: Geneva.

43. Winskill P, Rowland M, Mtove G, Malima RC, Kirby MJ. 2011. Malaria risk factors in north-east Tanzania. Malaria Journal, 10,98 .
44. Yentür Doni NYZF, Simşek Z, Zeyrek D. 2014. The effects of intestinal parasites on anemia of children. Turkiye Parazitolojii Dergisi, 38(2), 85-90 (in Turkish)

Cite this article as: Maghendji-Nzondo S, Nzoughe H, Lemamy GJ, Kouna LC, Pegha-Moukandja I, Lekoulou F, Mbatchi B, Toure-Ndouo F \& Lekana-Douki JB: Prevalence of malaria, prevention measures, and main clinical features in febrile children admitted to the Franceville Regional Hospital, Gabon. Parasite, 2016, 23, 32.

\section{O PARASTE}

An international open-access, peer-reviewed, online journal publishing high quality papers on all aspects of human and animal parasitology

Reviews, articles and short notes may be submitted. Fields include, but are not limited to: general, medical and veterinary parasitology; morphology, including ultrastructure; parasite systematics, including entomology, acarology, helminthology and protistology, and molecular analyses; molecular biology and biochemistry; immunology of parasitic diseases; host-parasite relationships; ecology and life history of parasites; epidemiology; therapeutics; new diagnostic tools.

All papers in Parasite are published in English. Manuscripts should have a broad interest and must not have been published or submitted elsewhere. No limit is imposed on the length of manuscripts.

Parasite (open-access) continues Parasite (print and online editions, 1994-2012) and Annales de Parasitologie Humaine et Comparée (1923-1993) and is the official journal of the Société Française de Parasitologie. 